authority on Saskatchewan plants, has ever heard of yellow chokecherries before.

Speaking at our Annual Meeting, Mr. D. K. Robinson, of the University Extension Department, said that similar berries had been located at two otker points in the province.

\section{Lillies and Bluebells}

\section{Stuart Froncis, Torch River}

O UR beautiful Yellow Wild Lily had three lovely blooms this past season. The blooms lasted for quite a number of days before starting to wilt, which was probably due to the cooler temperature than is usual at that season. Our other unusual Wild Lily also had two nice blooms. The native Bluebell (Tall Mertensia) also seemed to have its blooming, season just about double in length of time as compared with other years.

We were very interested in A. J. Breitung's article on "Carnivorus Plants", and hope to meet him personally some day. These plants are native to this area.

\section{A Hand Painted Guide to the Flowers and Birds of the Prairie}

$\mathbf{W}^{\mathrm{E}}$

were very pleased and thrilled

on receiving from Mr. Hugh McLaughlin, of Lewvan, an illustrated nature book of wild flowers and birds. But this is no ordinary nature book. It contains the original paintings of 36 common prairie flowers and 23 of our most common birds. The descriptive notes about each specimen gives extensive information about first appearance, habitat, family, environment, field marks, etc. It is a work of which the author may be justly proud. In respect to it Mr. McLaughlin writes:

"I couldn't lay my hands on a book that contained "my" wild flowers and birds, so I had them definitely identified and then drew a specimen of each.
That's how I feel about the BLUE JAY. We need a Natural History Magazine and Society in and for Saskatchewan. I appreciate the efforts of those who made and make it possible. You mentioned the "Kingdom of Nature"-and that in our Society one may enter with a love of flowers or birds or rocks, and that we all benefit from one another.

I don't imagine there is anything new or of value to the magazine in the contents of my little book-still it acts as a sort of ambassador to convey my interest and desire to help you."

\section{Random Botanical Notes}

\section{A. C. Budd}

AST fall several items were noted in the press regarding fall blooming of Crocus Anemone, and suggesting that such was unprecedented. This is not the case and I find Dr. G. M. Dawson reports away back in 1873 that these plants were blooming on August 7 and in the second week of September at Turtle Mountain and Long River. Last year I noted them on August 30 and this year several were blooming September 13. The Moss Phlox also occasionally shows fall flowering and in 1946 it bloomed near Webb on September 19, and this year I noted it on September 12 at Cadillac and on October 1 and 10 locally.

A plant of Milk Thistle, Silybum Marianum, has been found as a garden weed at East End, Saskatchewan. This is apparently the first record of this plant for the prairie provinces and was identified by Dr. C. Frankton of Ottawa.

Wild Pansy, Viola arvensis, was found north of Wilkie, Saskatchewan this fall. The only previous record seems to be that of $\mathrm{Mr}$. L. T. Carmichael, who located it at Canora, Saskatchewan.

Bitter Cress, Cardamine pennsylvanica, was found last June in the Cypress Hills. All previous records seem to have been from the northern parts of the province. 